\title{
設計事務所における仕様・コストの確定過程 DECISION PROCESS OF SPECIFICATION AND COST IN DESIGN FIRM
}

\author{
李 永 鎬*, 古阪 秀三**, 長 岡 弘明*** \\ Youngho YI, Shuzo FURUSAKA and Hiroaki NAGAOKA
}

\begin{abstract}
This paper surveys cost estimating process of a multiple dwelling project in a design firm, as the first step for developing cost estimating system. The firm used CAD at the early stage of design. We clarified that decided specifications were not fully utilized. Then we showed that, if we utilized the decided specifications completely and also utilized default values given by the design firm, estimated costs of a structural work and finishing work are very effective for adjusting of construction cost. Based on those findings, we proposed a new method for adjusting and converging construction cost during design stages.
\end{abstract}

Keyword : design firm, $C A D$, specifications, construction cost, cost estimation, cost planning 設計事務所，C A D，仕様確定，建築工事費、コスト算出，コストプランニング

\section{1.はじめに}

設計事務所におけるコストプランニングは設計業務の一つとして 規定されている(进1)。しかし設計と施工が組織的に分離されている 事を主な原因として，設計者が単独で精度のよいコストプランニン グを行うことは困難である事が多い。従って設計者は実施設計終了 後，施工者の工事見皘から実際の工事価額を把握し，建築主の目標 工事費を上回っておれば，設計変更によって目標工事費との差を解 消する傾向が強かった(生2)。

しかし，近年，建築工事費に対する建築主の要求が笅しくなる傾 向にあり (过3)，早期から，与えられた目標工事費と設計内容の整合 性を求める事など，コスト関連業務への要求が強まりつつある。 設計情報は，設計段階が進むにつれて詳細化し，かつ変更を繰り 返しながら確定される。とくに最近のCAD（Computer Aided Design）化の普及及び進展は，早期から設計情報の確定度を高めて おり，各設計段階におけるコスト算出・調整は，確定された設計情 報をできるだけ活用したものでなければならない。

基本計画，基本設計段階において，一般に広く行われているコス 卜算出は, 坪単価に基づいて行われており、これらの設計段階で確 定された設計情報を十分に活用していない事が予想されるが，その 実態は明らかではない。また，提案されているコスト算出方法は，

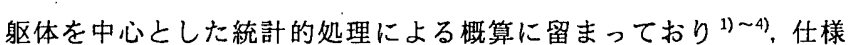
の詳細化を考虑した総合的なコスト算出・調整方法に言及したもの

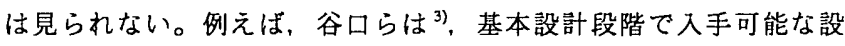
計情報を基に，身体数量との関係を分析し，いくつかの概算モテル を提案しているが, 躯体数量の算出において, 直接影響を及ぼす柱, 梁の断面積、休、壁の厚さ等の具体的な設計寸法を用いたモテルで はない。西沢らは の工事費を直接算出しているが, プロジェクトの個別性がコスト算 出に充分に反映されているとはいいがたい。

このように，提案されているコスト算出方法は，各設計段階で入 手可能な設計情報を十分に反映し，目標工事費と設計内容の整合性 を確保できるコスト算出・調整方法には至っていない。さらに進展 の著しいCA D 化の特性を活用した概算方法は見当たらない。

本諭文では，設計事務所のコスト算出・調整の央態を，CADを 使って設計を行った1つのプロジェクトを詳細に分析することによ り把握し，それに基づいて以下の検討を行う。

1）各設計段階で確定した、コスト関連設計情報は何か。

2)設計情報の内，実際のコスト算出・調整に用いられた情報は何か。 3）工事費の確定と関連し，実際に設計情報は，どのような特徵を 持って確定されるか。

\footnotetext{
* 京都大学大学院建築学尃攻 大学院生.工修

** 京都大学大学院建築学専攻 助教授.工博

*** 京都大学大学院建築学尃攻 教授・工博
}

Graduate Student, Dept. of Architecture, Graduate School of Eng., Kyoto University, M. Eng.

Assoc. Prof., Dept. of Architecture, Graduate School of Eng., Kyoto University, Dr. Eng.

Prof., Dept. of Architecture, Graduate School of Eng., Kyoto University, Dr. Eng. 
4)確定された設計情報を、コスト算出に十分活用するよう努力した 場合、算出した工事費はどのような特性を持っているか。

5) 設計情報をできるだけ活用したコスト算出・調整は，どのように 行えばよいか。

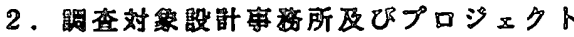

調查対象として中規模の共同住宅をとりあげる。調查はプロジェ クトを担当した設計者へのヒアリング，ならびに設計図面，台帳等 の関連盗料の検討によった。プロジェクトの概要を表 1 に示す。本 プロシェクトは基本計画段階からC A Dを用い設計を行った。設計 事務所は所員 27 人の中規模事務所である。本設計事務所のコス卜 算出・調整に関する特徵を述へると次のとおりである。

1)所員が意匠設計者のみで構成され，所員の中にコストプランニン グの専門的な知識を持つ者がいない。

2)手掛けるプロジェクトの種類が限られており，一定のデータ収集 が比較的容易であるにも関わらず，過去の実績から得られるコス 卜評価の知識, ノウハウの蓄積が組織的に行われていない。

3）設計情報が有効に活かされたコスト算出・調整方法がない。しか し設計事務所におけるコスト算出・調整方法のニーズは大きい。 各設計段階における算出・調整コストの精度は, 当設計段階で入 手可能な設計情報の確定度と、コスト算出方法に依存している。そ こで, 各設計段階で入手可能な設計情報とコスト算出・調整に実際 に用いられた設計情報、コスト算出・調整方法, 算出主体について 調查を行った。

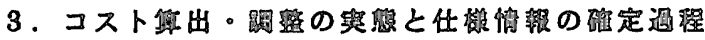

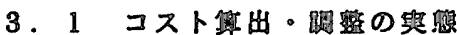

各設計段階におけるコスト算出・調整の調查結果を図 1 に示す。 前述のようにCADを使って設計を行ったため，基本計画段階から 躯体部位寸法にテフォルト值としての数值が与えられている。図 1 は左の方から右の方へ設計段階が進捗している状態を示している。 各設計段階の定義は次の通りである。(JIA「建築家の業務」, 建設省 告示 1206 号等にいう企画，基本設計等の定義と異なり，当該調㚗対 象設計事務所が用いている定義である。)

1) 企画：建築主の要求を中心とした各種の設計条件から建物の種

類、㙉造種別，建物の大まかなグレード，延床面積，階数など を決める段階。

2) 基本計画 : 企画での決定事項を基に柱割り，住戸部，共用部など の機能別面積，建物の形状，主要部の仕様グレードなどを設計 する段階。

3）基本設計：基本計画で決定された内容を基に，各部の寸法，面皘 などをさらに具体化し，断面図等を作成する段階。この段階で確 定された設計情報を基に建築確認申請を行う。

4）実施設計：基本設計を詳細化し，仕様情報を確定する段階。この 段階で確定された設計情報を基に積算する事ができる。

表 1 調亘プロジェクト

\begin{tabular}{|c|c|c|c|c|}
\hline \multirow[t]{3}{*}{ 用途 } & 店舗＋共同住宅 & \multirow[t]{2}{*}{ 高さ (m) } & 通高高さ & 15 \\
\hline & 1F:貨店铺 & & 鼠高亁高 & 14 \\
\hline & 2F～5F：共同住宅 & \multirow[t]{3}{*}{ 面皘 $\left(\mathrm{m}^{2}\right)$} & 僌地面秷 & 155 \\
\hline 描造形式 & HC造、ラーメ゚ン權造 & & 建筑面䨢 & 137 \\
\hline 谐数 & 地上5階 & & 延床面橮 & 681 \\
\hline
\end{tabular}

5) 設計番查: 実施設計で決定された設計内容を基に, プラン, 材料 仕样等の検討を行い，改善点を提案するなど，設計内容の合理化 を図る段階。

図 1 上部の「コスト関連設計情報」は各設計段階で確定されたコ スト評価に有用と考えられる仕様を表す。以下，仕様情報と記す。 「詳細化・変更情報」とは直前の設計段階の任様情報に基づき，当該 の設計段階でさらに詳細化あるいは変更修正の行われたものを「新 規付加情報」とは当該設計段階で初めて設計された情報を表す。仕 様情報の中でハッチした部分はコスト算出に実際に用いられた仕様 情報を示し，図1下部の「コスト算出・調整に使用された設計情報」 に改めて示している。「コスト算出・調整に使用された設計情報」と 「コスト算出・調整方法」に基ついて求めた坪単価または工事費総額 を図 1 の中間部に示す。企画，基本計画，基本設計完了時において は，坪単価が決定され，それに基づいて総額が計算され，実施設計， 設計審㚗完了時においては, 通常の積算手順に従って工事価額が決 定され，それに基ついて坪単価を計算している。先に決定されたも のをハッチして示している。コスト算出を行った主体を下部に示す。

\section{（1）コスト算出・調整方法}

企画段階で建築主より用途は専用共同住宅とし，目標坪単価 70 万円が提示された。設計者は施工会社の実勢坪単価の提示を基に， 70 万円の坪単価を設定したが、建築主がよりグレードの高い建物 を要求した。設計事務所では外壁，共用ホール部分でよりグレード の高い仕様の設定と 5 階のロフト工事, 地下受水槽のピットエ事, エレベーターエ事の追加を行い,これらによる坪単価の増加を 10 万円/坪とみなし，坪単価を 80 万円とした。坪単価の増加は，類 似物件等を参考にしたものではなく，設計者の主観的判断によるも のである。実勢坪単価 70 万円の内訳は図 1 の企画段階の「コスト 算出・調整方法」に示している。

基本計画段階では，目標坪単価に近づけるため，5階のロフトエ 事を中止し，75 万円/坪のコスト算出を行った。 5 万円/坪の単価 減少の算出根拠は, 設計者の主観的判断による。

基本設計段階で専用共同住宅が店舗及び共同住宅に変更された。 設計内容の詳細化，変更，新規付加に対して，新たにコスト算出は 行わず，基本計画の坪単価をそのまま使用している。即ち，柱，大 梁の断面寸法, 共用ホール，外壁等の仕様の詳細化，変更，新規付 加はコスト算出・調整に反映されていない。

実施設計段階から建等主と協議の上，施工会社を特命し工事費見 積を行わせている。企画から基本設計段階までは，坪単価と延床面 皘から工事費を算出し，実施設計段階からは工種別に工事費を積み 上げて積算を行っている。各設計段階で算出された坪単価の変動と 目標坪単価を図 2 に示す。

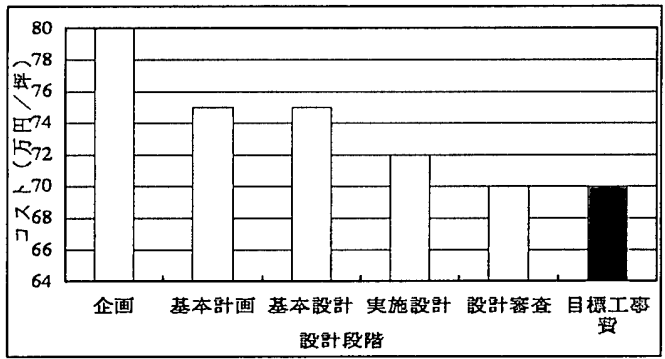

図 2 各設計段階における坪単価 


\section{（2）コスト算出・調整の特徵}

コスト算出・調整における特徵として次の事をあげる事ができる。

(1)企画段階で施工会社へのヒアリングから得た類似物件の実勢坪単 価を基準値とし，企画段階においては，類似物件との仕様の差異 から坪単価を加算し，基本計画，基本設計段階においては，前段 階の坪単価から，前段階からの変更仕様のみを対象にして，坪単 価を減じている。

(2) 坪単価の精度については, 次の 2 点から問題を有している。坪 単佃の変更を,変更仕様のみに対して行い，詳細化された仕様， 新規に付加された仕様情報はコスト算出・調整に使用していない。 また，坪単価の変更值は設計者の主観に基づいて設定している。 (3)企画，基本計画，基本設計段階において，坪単価についての上記 の問題点を承知の上で，設計者は経験的に，実施設計，設計審查 段階で，目標坪単価に収束可能と判断し，業務を進めている。

\section{2 仕槏情報の性格之砤定過程}

各設計段階で、躯体と仕上仕様がどのように確定されているかを， 次に検討する。

用語について次の定義をする。
1）仕様情報は，次の 2 情報から成る。

(1)部位寸法情報：各設計段階で決定される部位の位置，面積，断面 寸法等に関する情報。特に仕上仕様においては仕上数量の算出に 直接関わる寸法情報を指す。

(2)材料仕様情報：各設計段階で決定される部位の材料仕様に関する 情報。

2）仕様情報の決定レベル，方法に関して次の 4 つを用いる。

(1)テフォルト值：設計事務所やC A D において標準的仕様として仮 に設定する任様情報。確定值に至るまで随時その值は変更される。 (2)経験値：設計者の個人的経験によって設定される値。

(3)建築主の要望値：建築主の要望によって設定される值。建築主の 要望によって確定される材料仕様など。

(4)計算值・設計値：ある部位の仕様決定において、計算、テータか ら根拠を持って設定される值。構造計算による柱, 梁の断面寸法 など。

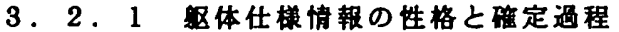

（1）部位寸法の確定過程

図 3 (a) の上段は躯体における部位寸法の確定過程を，図 3 (b)

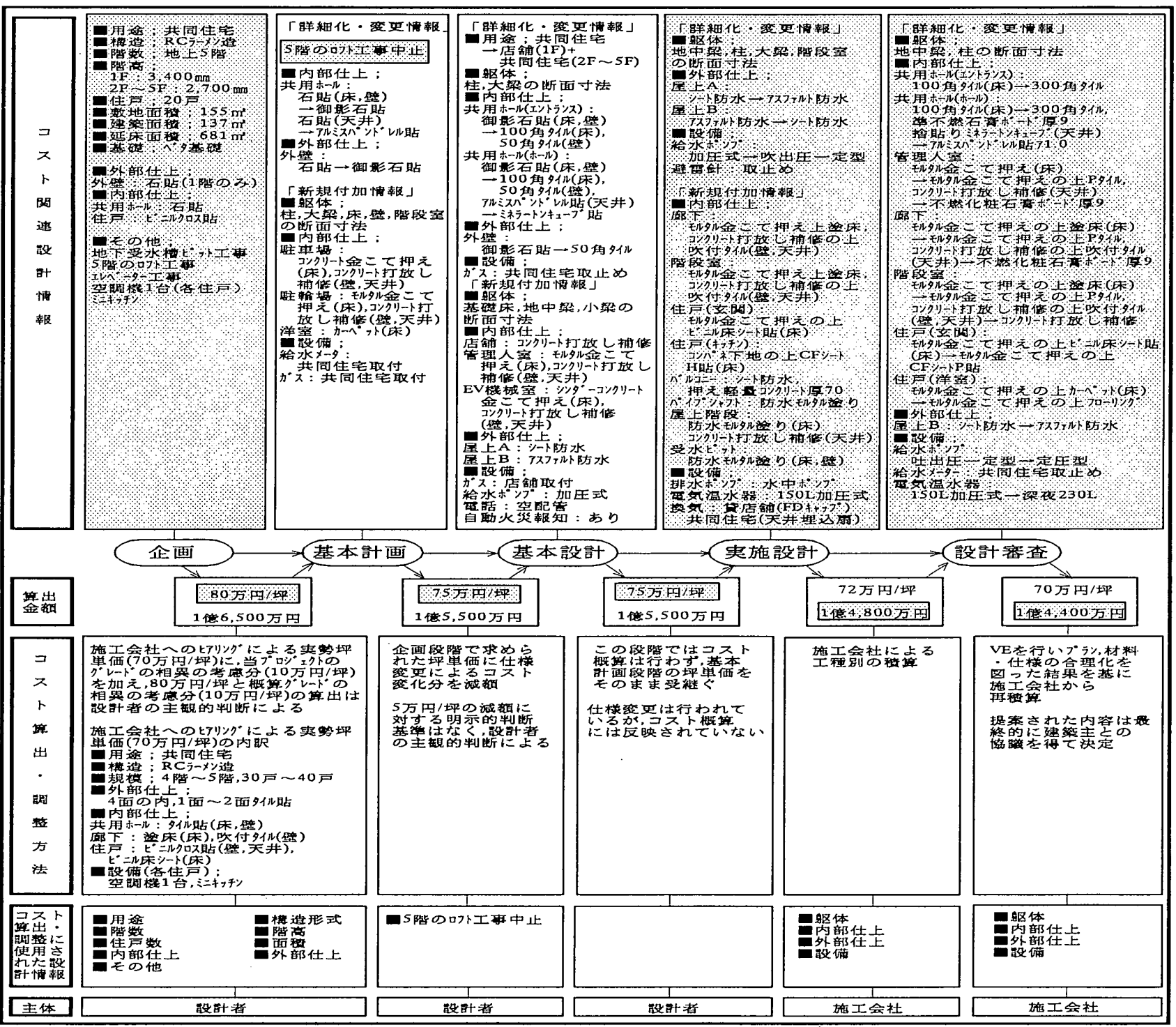

図1＼cjkstart各設計段階におけるコスト算出・調整 
に柱を例として断面寸法の確定過程を示す。

「基碳躯体」:企画段階では周辺のボーリングデータに基づき，基 䂣杭の有無と基碦形式が設計事務所のテフォルト值によって決定さ れる。部位寸法は，基䃈床面積のみ設定されている。基本計画段階 では基礎床面積のみ設定されており，地中梁の断面寸法に関する記 述はないが，この段階で設計事務所のテフォルト值を用いて地中梁 の概略断面を仮決定する事ができる。基本設計段階では基䃈床の厚 さと地中梁の断面寸法が構造設計者の計算值によって設定される。 実施設計段階で構造設計者の計算値に基づき, 基嘫床, 地中梁の断 面寸法の確定が行われる。設計審查段階では地中梁の梁せいの変更 $(2,000 \mathrm{~mm} \rightarrow 1,500 \mathrm{~mm})$ が行われている。

「地上躯体」: 企画段階では建築面積，延床面稍，階数、階高等が 決定され，それに基づいて各階の床面皘のみ設定される。基本計画 段階では, 設計事務所のテフォルト值を用いて床, 柱, 大梁、壁、 階段の概略断面が記述されている。これらの值は基本設計段階で計 算值によって置き換えられる。小梁の断面寸法に関する記述は基本 計画段階ではなく，基本設計段階で初めて計算值によって設定され， 実施設計段階で柱, 大梁等の断面寸法と共に計算値によって確定さ れる。設計審查段階では柱断面寸法の変更が行われている。

(2) 材料仕様の確定過程

図 3 (a) の下段は躯体における材料仕様の確定過程を，図 3 (c) では柱を例として材料仕様の確定過程を示している。企画段階では 構造種別の決定に伴って「鉄筋」と「コンクリート」の大まかな種 類のみが設計事務所のテフォルト值によって決定される。基本計画 段階においても，各部位の材料仕様の詳細な指定はない。基本設計 段階では構造設計事務所の計算值に基づいて断面寸法の決定が行わ れているが、材料仕様の詳細化は行われていない。央施設計段階て は，計算值によるコンクリート強度，鉄筋の種類、本数等の材料仕 様の詳細な情報が確定される。設計審査段階ては，地中梁之，地上 躯体の柱, 大梁の断面寸法の変更に伴って，一部の鉄筋の材料仕様 が変更されている。

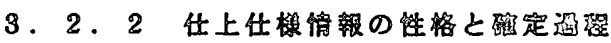

（1）部位寸法（仕上数量）の確定過程

企画段階では部位寸法に関する記述はなく，基本計画段階で初め て部位寸法が設計者の経験值と設計事務所のテフォルト值によって 決定され，各部位の仕上数量を求める事ができる。これらの部位寸 法は躯体数量の変化之建筑計画上の変化により，変更を繰り返すが， 建筑計画上の平面の確定に従い，部位寸法の変動は少なくなる。設 計審查段階では共用ホール、外壁の部位寸法の変更が行われている。 （2）材料仕様の確定過程

図 4 は仕上材料仕様の確定過程を示す。図 4 の企画から基本設計 段階の「記述なし・テフォルト値」に表している仕樣情報は，各部 位に対する設計事弱所のテフォルト値を示している。企画段階では 施工会社へのヒアリング調査による仕様情報を基に，建築主の要求 に対応して，外壁，共用ホール，住戸といった主要部分の材料仕様 が大まかな形て決定されている。外壁，共用ホールの材料仕様の決 定は建筑主の要望值，住戸部は設計事務所のテフォルト值によるも のである。基本計画段階では企画段階の仕様情報を基に，共用ホー ル，外壁の仕様詳細化が行われている。新規付加情報として駐車/ 䇠輸場，洋室の床等の材料任様が設定されている。基本設計段階て
は建築主との調整の上，共用ホールの床・壁，外壁等の材料仕様の 変更が行われている。新規付加情報として貸店舖, 管理人室, EV 機 峨室，屋上等の材料仕様がある。実施設計段階ては屋上材料仕様の 詳細化及び変更が行われている。新規付加情報として廊下，階段室， バルコニー，パイプシャフト，屋上階段、受水ピットの各部の材料 仕様と住戸部の玄関・キッチンの床材料仕様等が設定されている。 設計審查段階ではValue Engineering (以下VEと記す) を実施し，ナ ラン、材料仕様の見直しを行った結果，共用ホール，管理人室，廊 下，階段室の各々の床・天井，住户部の玄関、洋室の床，屋上等の 材料仕様の変更が行われている。共用ホール，管理人室，住戸部の 洋室，屋上の仕様グレードは上がり，廊下，階段室，住戸部の玄関 等の仕様グレードは下がっている。VE実施は設計事務所を中心に構 造，設備設計事務所とゼネコン，サブコンとの共同で行われた。

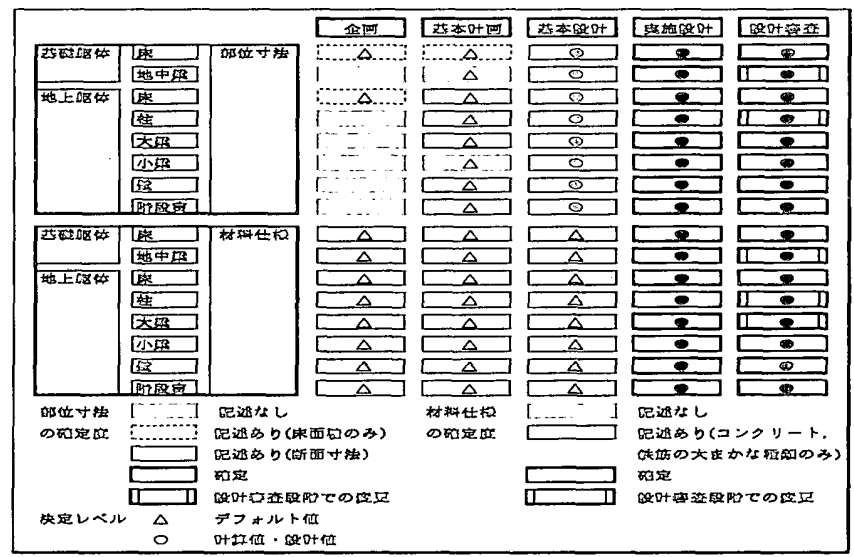

図 3 (a) 躯体仕様の確定過程

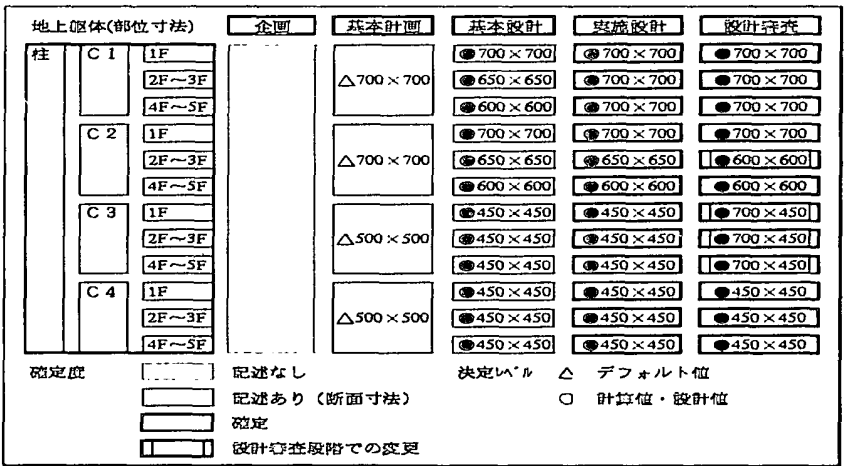

図 3 (b) 柱断面寸法の確定過程例

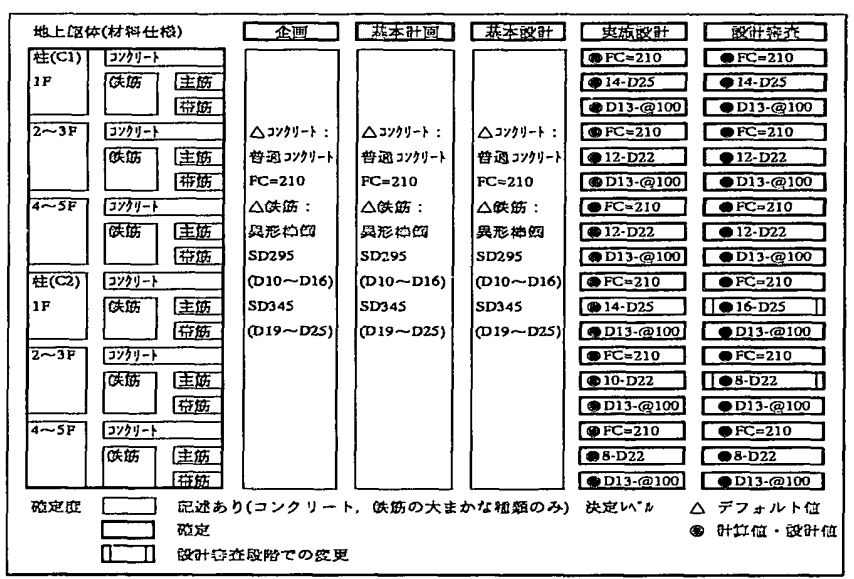

図 3 (c) 柱材料仕様の確定過程例 


\section{4、コスト閶連陪计情報の特微}

以上の調查結果に基づき，コスト関連設計情報，即ち，仕様情報 の特徵を、以下に検討する。ここでは簡単のために仮設費，土工事 費，設備工事費を除いて検討する。当該プロジェクトで与えられた 目標坪単価 70 万円のうち，上記の工事費を除いた金額は約 78 , 000千円であり，これが躯体工事費と仕上工事費に使用可能な工 事費となる。以下，この金額を狭義の目標工事費(俚4)とみなす。

\section{1 欺体仕様の特微}

\section{1. 1 総コンクリート数量}

企画段階で鉄筋コンクリート構造である事が確定され，基本計画 段階で延床面積，階数、スパン等が決定されると，柱，梁等の断面 寸法が設計事務所のデフォルト值によって仮決定される。以後，棈 造計算等により断面寸法が確定されていくに従い,テフォルト值は 計算値に置き換えられる。計算值，及び計算值のない数量はテフォ ルト值を用いて、躯体の総コンクリート数量を算定した結果を，図 5 に示す。設計審査段階の総コンクリート数量に対し，各設計段階 の総コンクリート数量の変動は最大 $2.2 \%$ 2 あり, 総コンクリー
ト数量の変動は小さい。

\subsection{2 般体工事費}

基本計画，基本設計段階における総コンクリート数量を基に, 次 式により躯体工事費を算出する。

$$
\begin{aligned}
S & =C+F+R \quad \cdots(1) \\
C & =C_{s} \times C_{c}, \quad F=C_{s} \times \alpha \times F_{C,} \quad R=C_{s} \times \beta \times R_{C}
\end{aligned}
$$

$S:$ 躯体工事費（円）

$C:$ コンクリート工事費 (円)

$C_{s}:$ コンクリート数量 $\left(\mathrm{m}^{3}\right)$

$C_{C}:$ コンクリート単価 (材工共) $=15,085\left(\right.$ 円 $\left./ \mathrm{m}^{3}\right)$

$F:$ 型枠工事費 (円)

$\alpha:$ 型枠/コンクリート比 $\left(\mathrm{m}^{2} / \mathrm{m}^{3}\right)=5.86$

$F_{c}$ : 型杵単価 (材工共) $=3,935\left(\right.$ 円 $/ \mathrm{m}^{2}$ )

$R:$ 鉄筋工事費 (円)

$\beta:$ 鉄筋/コンクリート比 $\left(1 / \mathrm{m}^{3}\right)=0.12$

$R_{C}$ : 鉄筋単価 (材工共) $=101,833($ 円 $/ \mathrm{t})$

\begin{tabular}{|c|c|c|c|c|c|c|c|}
\hline & & & 企画 & 基本站画 & 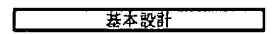 & 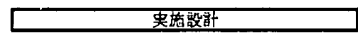 & 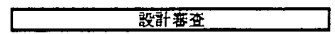 \\
\hline \multirow[t]{3}{*}{ 厚店霜 } & 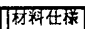 & 框 & 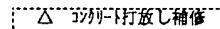 & & 口, & 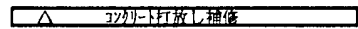 & Iy 21 - \\
\hline & & Eg & 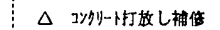 & & $\triangle \Delta \mathrm{I} / \mathrm{y} \|$ - & 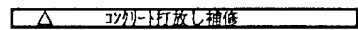 & 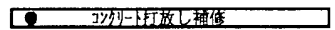 \\
\hline & & 因开 & 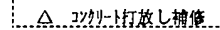 & & 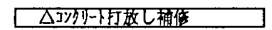 & 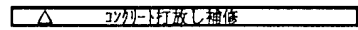 & 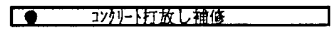 \\
\hline \multirow[t]{3}{*}{ 野車㻛 } & 网料在棬 & 述 & 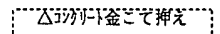 & 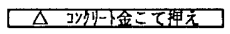 & $\Delta$ Im & 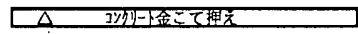 & 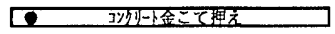 \\
\hline & & 監 & 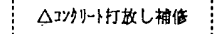 & 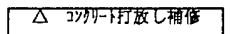 & 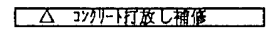 & 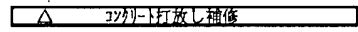 & 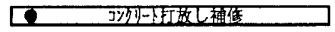 \\
\hline & & 医井 & 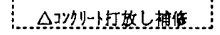 & & 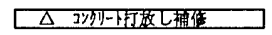 & 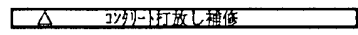 & I \\
\hline \multirow[t]{3}{*}{ 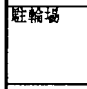 } & 网料程 & 萎 & 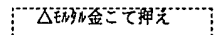 & 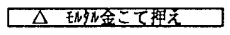 & 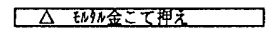 & 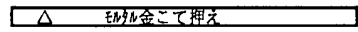 & 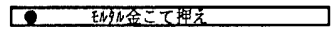 \\
\hline & & D地 & 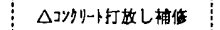 & 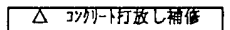 & 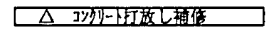 & $\triangle \Delta \quad$ J & 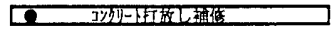 \\
\hline & & 因开 & 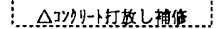 & & 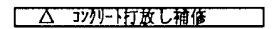 & 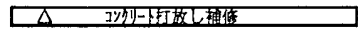 & 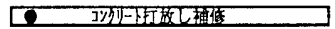 \\
\hline \multirow[t]{3}{*}{ 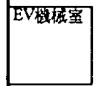 } & 网料在椂 & 述 & \multirow{2}{*}{\multicolumn{2}{|c|}{$\Delta{ }^{-1}$}} & 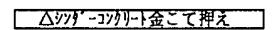 & 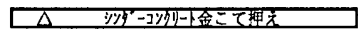 & 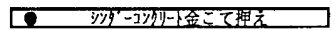 \\
\hline & & EE & & & 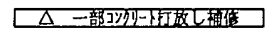 & 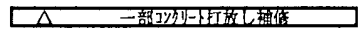 & 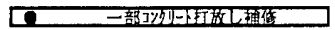 \\
\hline & & 洰井 & \multicolumn{2}{|c|}{ 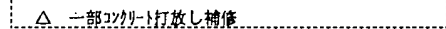 } & 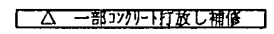 & 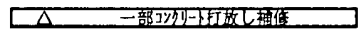 & 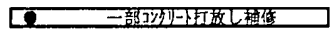 \\
\hline An $M=-$ & 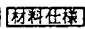 & 婪 & \multicolumn{3}{|c|}{ 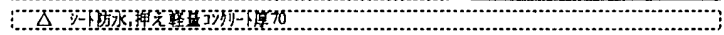 } & ; & 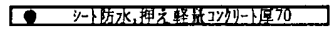 \\
\hline$n+77^{*}:+7+4$ & 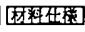 & 赖 & \multirow{2}{*}{\multicolumn{3}{|c|}{ 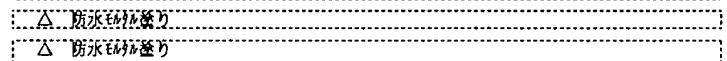 }} & 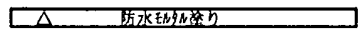 & 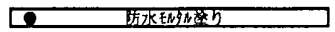 \\
\hline \multirow{2}{*}{ 属上管段 } & 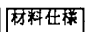 & 整 & & & & 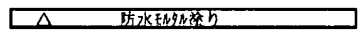 & 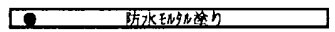 \\
\hline & & 医井 & 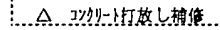 & & & 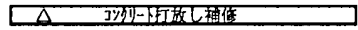 & 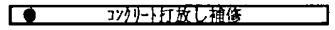 \\
\hline \multirow[t]{2}{*}{ 受水地 } & 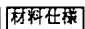 & 筺 & 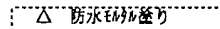 & & & 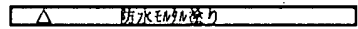 & 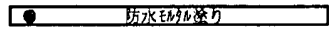 \\
\hline & & 㾏 & $\Delta$ 防水些q & & & 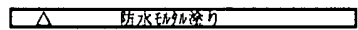 & 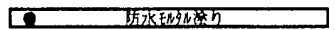 \\
\hline \multirow{3}{*}{ 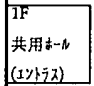 } & 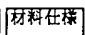 & 床 & & 傲㽎石貼 & (a) 100 角多机照 & 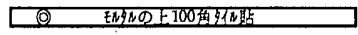 & 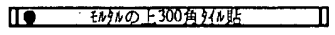 \\
\hline & & 朢 & (2) 石㽎 & & 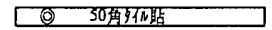 & 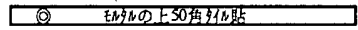 & 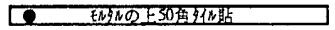 \\
\hline & & 医井 & & 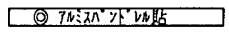 & 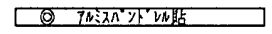 & 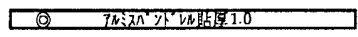 & 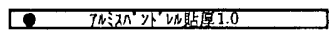 \\
\hline \multirow{3}{*}{$\begin{array}{l}1 \mathrm{~F} \\
\text { 共用 } \mathrm{d}-\mathrm{H} \\
(\mathrm{k}-\boldsymbol{M})\end{array}$} & 村料任抹 & 睏 & & (0) 御斯石貼 & (2) 100 西9110 & 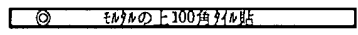 & 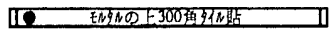 \\
\hline & & 恇 & (c) 石貼 & & 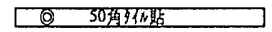 & 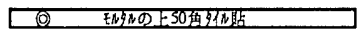 & 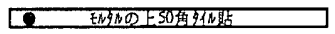 \\
\hline & & 葵井 & & 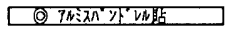 & 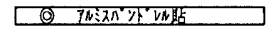 & 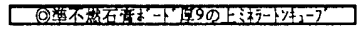 & 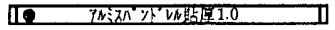 \\
\hline \multirow{4}{*}{ 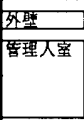 } & 因料任㥞 & & (0) 石䀡 & 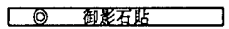 & (0) 50 细 & 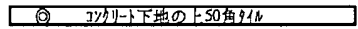 & 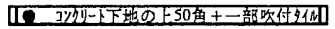 \\
\hline & 麻料任椂 & 医 & 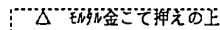 & 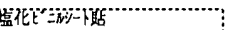 & 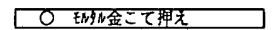 & 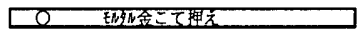 & 口曰 \\
\hline & & 匪 & 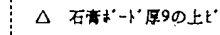 & $=x \geqslant 0 x$ & 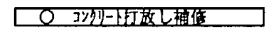 & 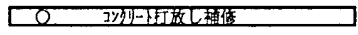 & 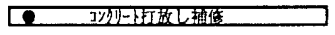 \\
\hline & & 园井 & 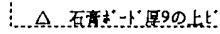 & $=m p a x$. & 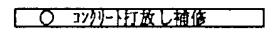 & 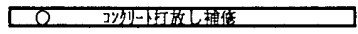 & 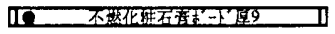 \\
\hline \multirow[t]{3}{*}{ 游下 } & 网料任磪 & 框 & 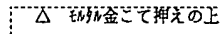 & & & 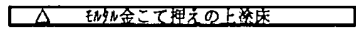 & 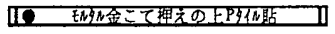 \\
\hline & & 壁 & 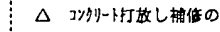 & 上吹付夕侎 & & 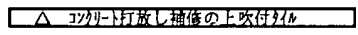 & 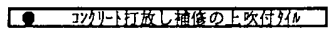 \\
\hline & & 医井 & 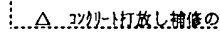 & 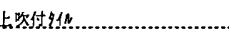 & & 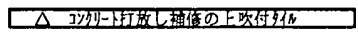 & 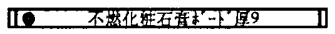 \\
\hline \multirow[t]{3}{*}{ 墸段菿 } & 原料在相 & 棦 & 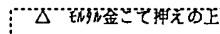 & 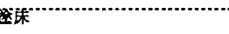 & & 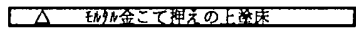 & 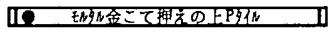 \\
\hline & & 匰 & $\Delta$ 丁ックリート打故し補借の & 上吹付 $\$$ 似 & & 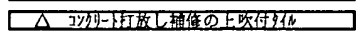 & 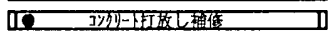 \\
\hline & & [国牛 & 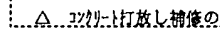 & 上跑付 41 . & & 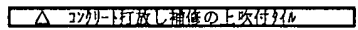 & 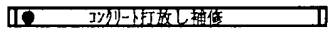 \\
\hline \multirow{3}{*}{ (萑启 } & 网料在檌 & 医 & 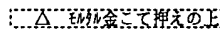 & r & and & 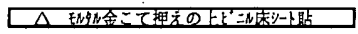 & 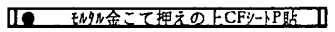 \\
\hline & & 䃌 & 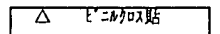 & 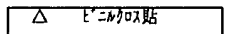 & $\triangle E^{\prime}=k / 0 \times 18$ & 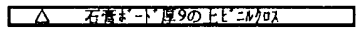 & 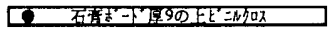 \\
\hline & & 医开 & & & 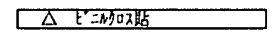 & 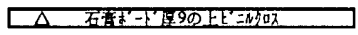 & 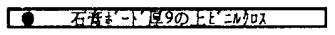 \\
\hline \multirow{3}{*}{$\begin{array}{l}\text { 㕍户 } \\
(+, f y)\end{array}$} & 网料任檴 & 医 & 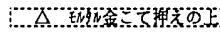 & 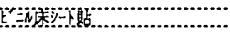 & 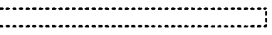 & 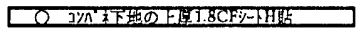 & 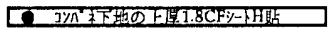 \\
\hline & & 壁 & $\Delta \quad l=w / 0 \times$ 㽎 & 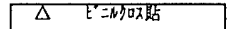 & $\triangle E=m$ 叹㸃 & 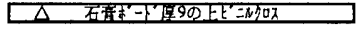 & 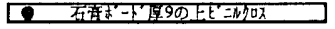 \\
\hline & & 医井 & & & $\triangle E^{2}=m$ 叭点 & 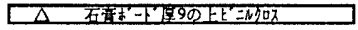 & 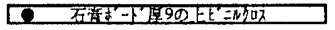 \\
\hline 住学 & 网料任㩰 & 压 & a.non & $\Delta \Delta_{n-1}^{*}, 1$ & $\Delta \Delta \quad t-1 \cdot 7$ & 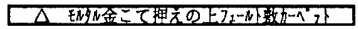 & 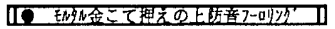 \\
\hline \multirow[t]{2}{*}{ (洋察) } & & 匰- & 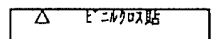 & 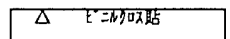 & $\triangle F=M, 0 \times g_{1}$ & 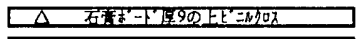 & 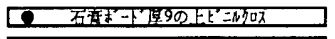 \\
\hline & & 因井 & & & 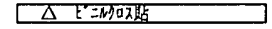 & 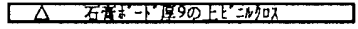 & 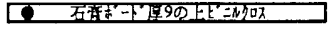 \\
\hline \multirow{6}{*}{ EEA } & 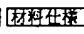 & 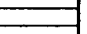 & 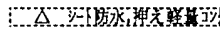 & 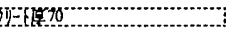 & 0 i-1房水 & 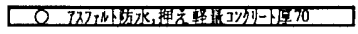 & 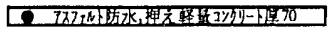 \\
\hline & 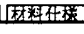 & & :- & bIE & 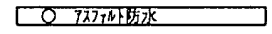 & 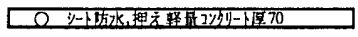 & 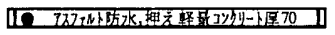 \\
\hline & 材料位模 & :........ & 記述なし & 決定以” & $\Delta \quad \ddot{r}^{\prime} J_{\text {JM值 }}$ & & \\
\hline & の砤定度 & $\square$ & 記述おり & & 程雅值 & & \\
\hline & & $\square$ & 确定 & & 建策主の罗望值 & & \\
\hline & & एप & 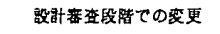 & & 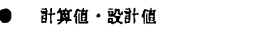 & & \\
\hline
\end{tabular}

(1) 式の $F ， R$ の算出に用いた $\alpha ， \beta$ の值之単価は調查対象事務

図 4 仕上材料仕様の確定過程 
所の類似実績から得たものである。

基本計画，基本設計段階に抢ける躯体工事費の算出金額，ならび に実施設計と設計審查段階における施工会社による積算金額を、表 2 に示す。設計審查段階の躯体工事費に対し，各設計段階における

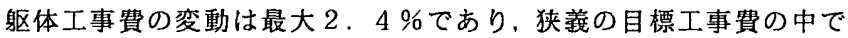
約 $1 \%$ の変動を表している。即ち，狭義の目標工事費の中で躯体工 事費の変動は小さい。

\section{2 仕上仕棑の徽}

各設計段階における仕上数量は躯体数量の変化之建築計画上の変 化により，各部位ごとに変更を繰り返すが，建築計画上の平面の確 定に従い，仕上数量の変動は少なくなる。また各部位の材料仕様グ レードは各設計段階を通して設計事務所のデフォルト值に基づいて 設計者の経験值や建築主の要望に依存しながら変更・確定されてい く。図 4 に示す仕上仕様を含めた，各部位の仕上仕様を，図 6 に示 すように，以下の 3 つの仕様群に分類することを考える。

a) 予め最低仕様により決定できる仕様 (A 群)

b) 建筑主の要望によって決定される仕様（B 群）

c) 設計者の意図によって決定できる仕様 ( $\mathrm{C}$ 群)

図 6 の左欗に示す部位の分類は，設計者へのヒアリングにより作 成したものであり，右概に各設計段階における仕様グレードの変更 経過を示している。貸店舗, 駐車場等の $\mathrm{A}$ 群の場合、基本計画から 設計審查段階まで仕様グレードの変更のない状洗を見ることができ る。B群である共用ホールと外壁では，仕様グレードの変更が建築 主との調整の上行われている。管理人室, 廊下等のC群においては， 設計者のみの考え(意図) で調整が行われている。表 3 は各設計段 階で確定された仕様情報、及びテフォルト值から算出した各仕様群 の工事費を示す。基本計画，基本設計段階の工事費は著者らによる 試算金額であり，実施設計，設計審査段階の工事費は施工会社によ る積算金額である。A群の工事費の変動は仕上数量の変動によるも のである。図 7 は各設計段階におけるA，B，C群の仕様群別の工 事費及び躯体工事費を示す。図 8 に躯体工事費と仕上工事費の和之， 狭義の目標工事費の関係を示す。図 8 より，各設計段階におりる躯 体及び仕上工事費の和は，基本計画の段階から大きな変化はなく， かつ狭義の目標工事費にほぼ近い值となっている。この事実は設計 者は知らない事実であるが, 設計の進行とともにテフォルト值から 設計值への変更で工事費の調整を行う場合，この情報により，格段

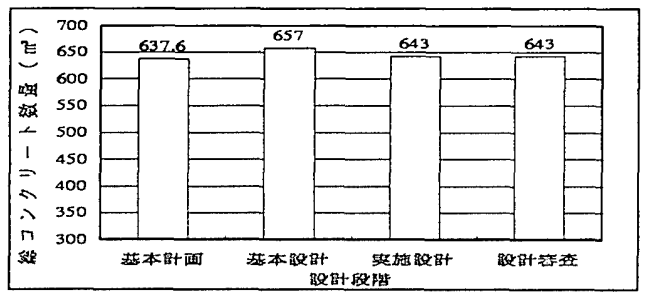

図 5 各設計段階における㥹コンクリート数量

表 2 各設計段階における躯体数量と工事費

\begin{tabular}{|c|c|c|c|c|c|}
\hline & & 基本部画 & 基本設訢 & 实施設計 & 設計摇查 \\
\hline \multirow[t]{2}{*}{ 㷕目 } & 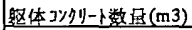 & 637.6 & 657 & 643 & 643 \\
\hline & 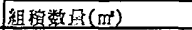 & $\mathrm{S}$ & 3 & 106.6 & 120.6 \\
\hline \multirow[t]{5}{*}{ 工事費 } & 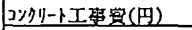 & $9,618,196$ & $9,910,845$ & $9,699,712$ & $9,699,712$ \\
\hline & 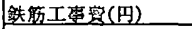 & $7,791,446$ & $8,028,513$ & $7,361,921$ & $7,445,446$ \\
\hline & 型柺工事窐 $(\mathrm{H})$ & $14,702,482$ & $15,149,828$ & $15,219,600$ & $14.424,900$ \\
\hline & 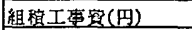 & 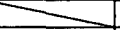 & P & 664,900 & 741,900 \\
\hline & 合㖕 & $32,112,124$ & $33,089,186$ & $32,946,133$ & $32,311,958$ \\
\hline
\end{tabular}

に調整が容易になるものと考えられる。

ここで実際に各仕様群の工事費について操作可能な範囲を試算し てみる。狭義の目標工事費 $78 ， 000$ 千円只胟体工事費を差し 引いた金額、即ち、基本計画段階で $45 ， 890$ 干円，基本設計段 階で 4 4，910 千円，実施設計段階で $45 ， 050$ 千円，設計審 查段階で 45，690干円が各設計段階における仕上工事に使用可 能な工事費となる。基本計画，基本設計段階の値と設計審查段階の

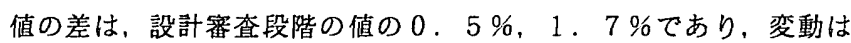
少ない。仕上工事費の最大操作可能範囲は，各設計段階における仕 上工事費から，A，B，C群を最低仕様とした場合の工事費を差し 引いた金額である。このうち、A 群は既に最低仕様であり，仕上工 事費の最大操作可能範囲は B，C群の最大操作可能範囲である。表 4 に各設計段階におけるA，B，C群の設計仕様と最低任様の工事 費を示す。 B，C群の最大操作可能範囲を求めると，基本計画段階 で $10 ， 320$ 千円，基本設計段階で 8，480 千 月，実施設計段 階で 8，510 千円，設計審查段階で 7，130千円であり，狭義 の目標工事費の中で約 $9.1 \%$ 1 3 . $2 \%$ の割合を占めている。 $\mathrm{B}$ 群の操作範囲は，基本計画段階で $6 ， 770$ 千円，基本設計段階

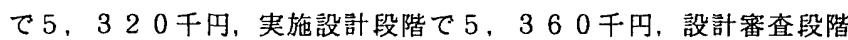
で 4，750 千円であり，上記の B，C群の最大操作可能範囲の中 で約 $62.7 \%$ ６６．6\%の割合を占めている。各設計段階にお ける C 群の操作可能範囲は，基本計画段階で $3 ， 550$ 千円，基本 設計段階で 3，160 千 円，実施設計段階で 3，150 千円，設計

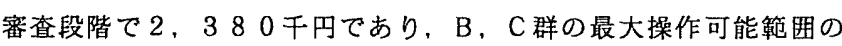
中で約 $37.3 \% \sim 33.4 \%$ の割合を占めている。

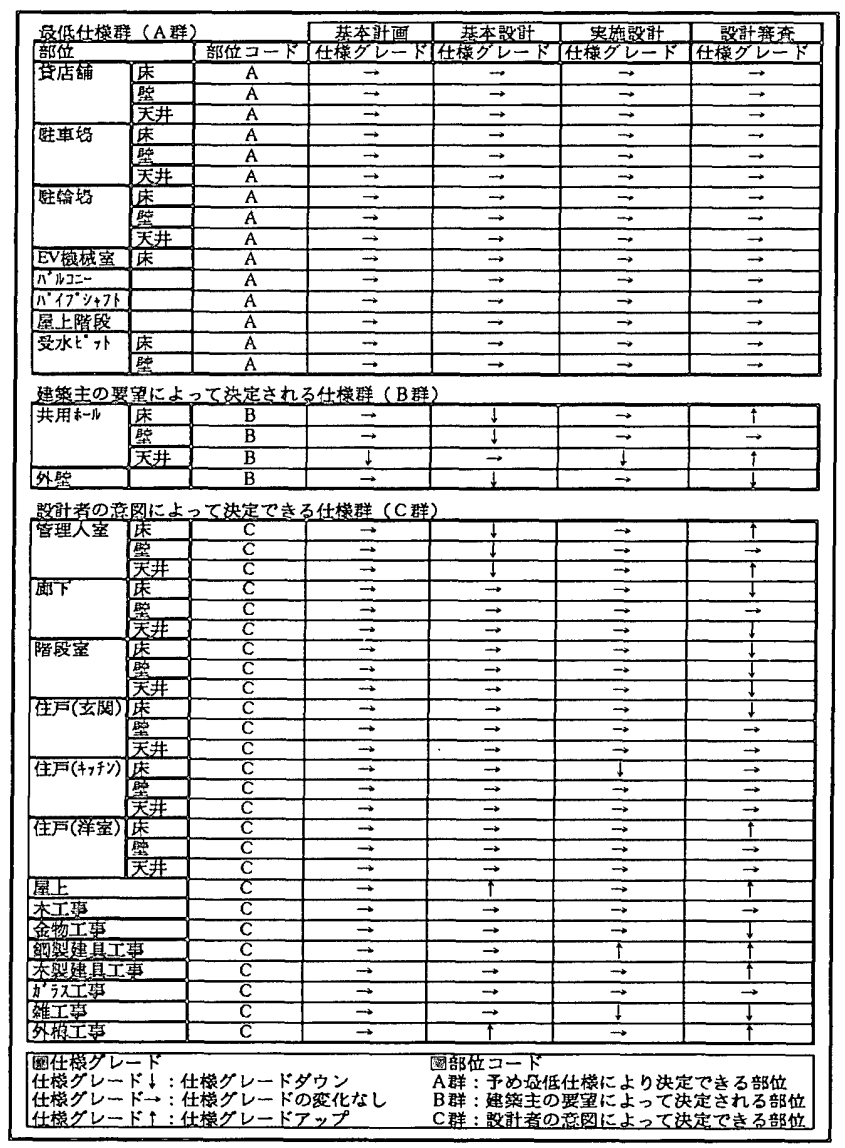

図 6 各設計段階における仕様グレードの変更経過 


\section{表 3 各仕様群の工事費}
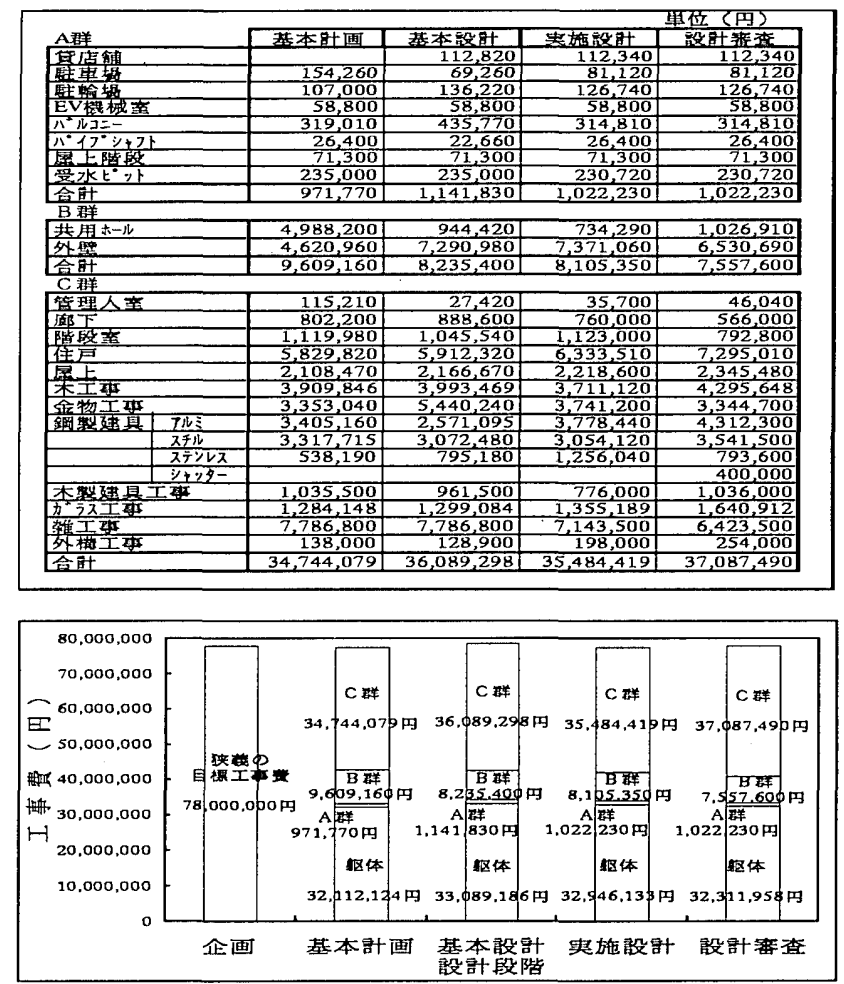

図 7 各設計段階における A， B，C群及び躯体工事費

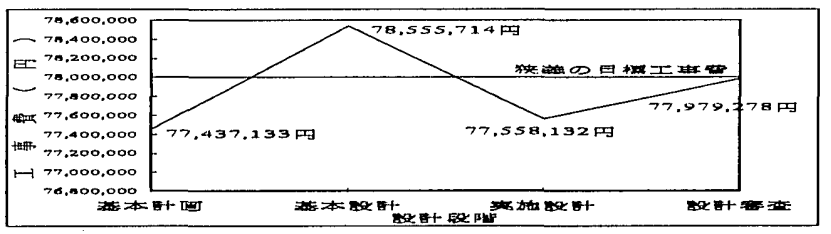

図 8 狭義の目標工事費と設計仕様工事費とのバラッキ

表 4 設計仕様と最低仕様による各仕様群の工事費

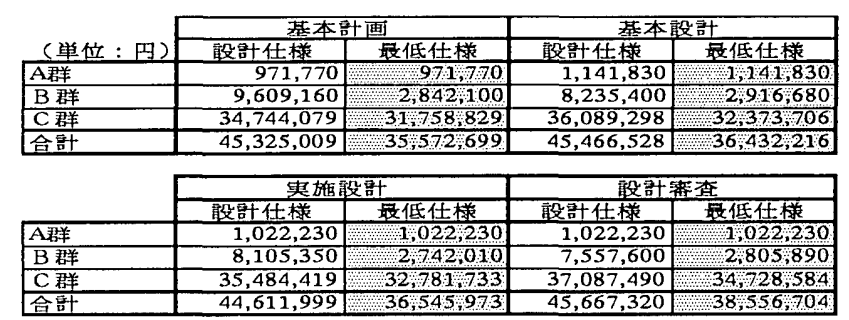

\section{5、コスト調方法の提案}

躯体, 仕上工事費の確定過程について得られた知見をまとめると 次のとおりである。

(1)躯体についての計算值, 計算值のない場合にはテフォルト值を用 いて，躯体数量を算出し，躯体工事費を求めた場合、基本計画以 後の躯体工事費は，狭義の目標工事費の中で的 $1 \%$ 変動を表し て㧍り，躯体工事費の変動の幅は小さい。

(2)狭義の目標工事費が与えられた場合，躯体工事費の変動の幅が小 さいことに伴って使用可能な仕上工事費の変動の幅も小さくなる。 (3)仕上工事費を前述のA，B，C群に分類して考える時，仕上工事 費の操作可能範囲は仕上工事費からA，B，C群を最低仕様とし た場合の工事費を差し引いて算出する事ができ。この時，A群 は既に最低仕様であり，上記の金額はB，C群の操作可能範囲と
なる。B，C群の操作可能範囲は狭義の目標工事費の中で約 9 . $1 \% \sim 13.2 \%$ の割合を, 使用可能な仕上工事費の中で約 15 . $6 \%$ 22，5\%の割合を占めている。

(4)操作可能範囲金額の内，B群が約 $65 \%$ ，C群が約 $35 \%$ を占め ており、コスト調整における建築主との協議が重要な位置を占的 ている。

(5) B 群の工事費は建築主の要望により決定できるが，B群での最低 仕様工事費との差は，本プロジェクトで平均 $200 \%$ あるる。C 群の工事費は設計者の意図により決定できるが，C群での最低仕 様工事費との差は，本プロジェクトで平均 $9 \%$ \%ある。

以上の知見より, 基本計画, 基本設計段階におけるコスト調整方 法を図 9 に示す。具体的に図 9 の手順を以下に示す。

手順 1) 目標工事費を設定する。

手順 2 ) 躯体についての計算值, 計算値のない場合はテフォルト值 を用いて, 柱, 大梁の他, 壁, 床, 小梁等の各コンクリート数量 を算出し、これらの総和として躯体コンクリート数量を算出する。 その時, テフォルト值は C A D を使って設計を行う事により早期 から必要となる。

手順 3 )「手順 2 」で算出した躯体数量に基ついて（1）式を用い て躯体工事費を算出する。

手順 4 ) 目標工事費から, 上記の躯体工事費を差し引いて仕上工事 費を算出する。

手順 5 ) 各部位の仕上数量を各設計段階で確定された仕様情報及び テフォルト值を用いて算出する。CADを使って設計を行う事に より，早期から部位寸法のテフォルト值，または設計者の経験值 が与えられ、仕上数量を算出する事ができる。

手順 6 ) 仕上仕様を A，B，C群に分類する。すへての仕様に対し て最低仕様を用い，仕上工事䚉の下限を算出する。

手順 7 ) 躯体工事費之， A， B，C群の仕上工事費の下限の合計が 目標工事費の中に入っているかを検討する。(目標工事費を越えて いる場合は，目標工事費の再検討を行う)

手順 8 ）仕上工事費から A，B，C群を最低仕様とした場合の工事 費を差し引いて，A， B，C群の操作可能範囲を算出する。この 時、 $\mathrm{A}$ 群は既に最低仕様であり、上記の金額は B、C 群の操作可 能範囲となる。

手順 9) B，C群の操作可能範囲の中で，まず建築主との協議によ るB 群の工事費を算出し，次に設計者の意図によるC 群の工事費 を算出する。この時，B群とC 群は相互依存的であり，仕様調整 のやりとりを繰返し，全体として操作可能最大值への収束を計る。 手順 10 )「手順 9 」で算出した工事費が目標工事費の中に入ってい るか，B，C 群のバランスはよいかを検討する。(目標工事費を越 えている場合，B，C 群のバランスの悪い場合は，B，C群の再 険討を行う)

手順 11 ）工事費の確定。

手順 12 ) 次の段階へ。

次の設計段階においても手順 2) 〜手順 11 ）の作業を繰返し目 標工事費への収束を計っていく。

これらの知見，及びそれに基つく調整方法の提案は，一つのプロ ジェクトの調查結果に基づくものである。他のプロジェクトへの適 用可能性については今後の検討が必要である。 


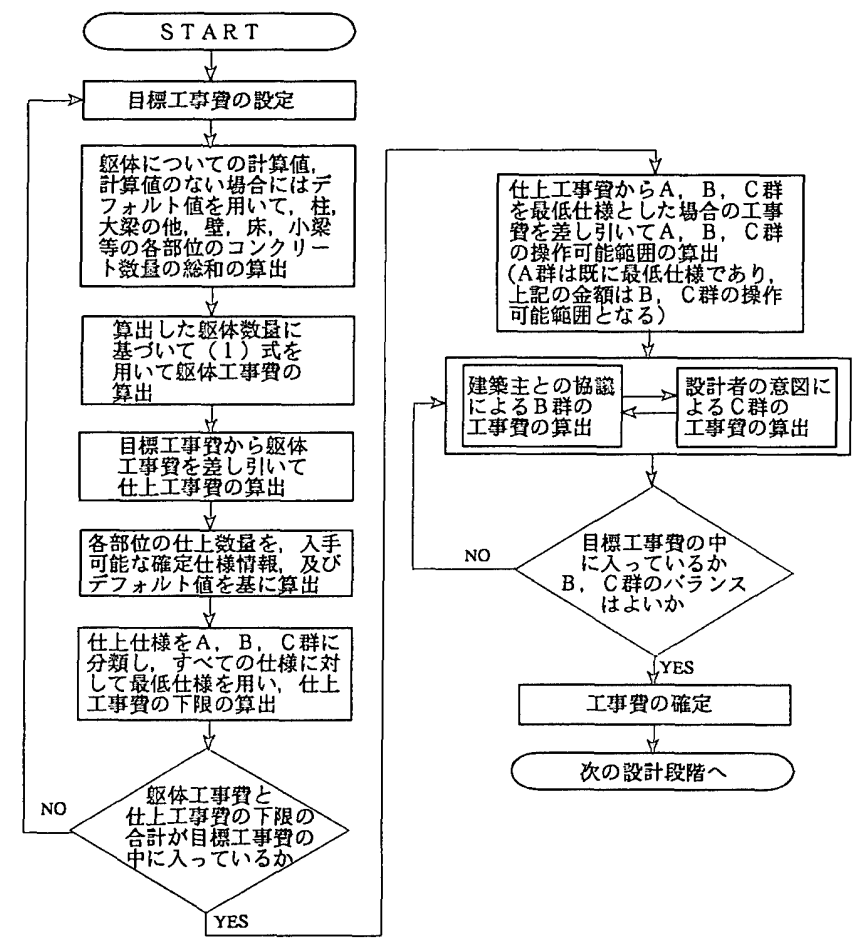

図 9 コスト調整の手順

\section{8. まと施}

本研究で得られた主要な知見は次の之おりである。

1) C A Dを使って設計を行った一つのプロジェクトを取りあげ、コ スト算出・調整の実態分析を行った。分析結果は次の通りである。 (1)企画段階で施工会社へのヒアリングから得た類似物件の実勢坪単 価を基準值とし，企画段階においては，類似物件との仕様の差異 から訐単価を加算し、基本計画，基本設計段階においては，前段 階の坪単価から，前段階からの変更仕様のみを対象にして，坪単 価を減じている。

(2)坪単価の変更值を，変更仕様のみに対して行い，詳細化された仕 様，新規付加された仕様情報を使用していない。また坪単価変更 值は設計者の主観に基ついて設定している。

2)各設計段階て確定された仕様情報，及び設計事務所で設定したテ フォルト值をコスト算出・調整に十分活用するよう努力した場合， 算出した工事費はどのような特徵を持って確定されるかを検討し た。その結果は以下のとおりである。

(1)躯体についての計算值, 計算值のない場合にはテフォルト值を用 いて，躯体数量を算出し，躯体工事費を求めた場合，基本計画以 後の躯体工事費は，狭義の目標工事費の中で約 $1 \%$ の変動を表し ており,躯体工事費の変動の幅は小さい。狭義の目標工事費は， 検討の単純化のため用いたものであり，建築主から与えられた目 標工事費から仮設費，土工事費，設備工事費を除いた，躯体工事 費と仕上工事費に使用可能な工事費である。

(2)狭義の目骠工事費が与えられた時，仕上工事費の使用可能範囲は 狭義の目標工事費から躯体工事費を差し引いた金額である。基本 計画，基本設計段階の值と設計審㚗段階の値の差は、設計審查段 階の值の $0.5 \% ， 1 ７ \%$ であり，変動は少ない。 (3)仕上仕様を次の 3 つの仕様群で分類する事を考えた。

a) 予め最低仕様により決定できる仕様 (A群) b) 建築主の要望によって決定される仕様（B 群）

c) 設計者の意図によって決定できる仕様（C 群）

仕上工事費の操作可能䉇囲は，仕上工事費から，A，B，C群を 最低仕様とした場合の工事費を差し引いて算出，把挃する事ができ る。この時， A 群は既に最低仕様であり，上記の金額は B，C 群の 操作可能範囲となる。B，C群の操作可能範囲は狭義の目禋工事費 の中で約 $9.1 \%$ 13.2\%の割合を, 使用可能な仕上工事費の 中で約 $15 ． 6 \% \sim 22.5 \%$ の割合を占めている。

(4)操作可能範囲金額の内，B 群が約 $65 \% ， \mathrm{C}$ 群が約 $35 \%$ を占め ており、コスト調整における建筑主との協議が重要な位置を占め ている。

(5) B 群の工事費は建築主の要望により決定できるが、B群での最低 仕様工事費との差は，本プロジェクトで平均 $200 \%$ あるるC 群の工事費は設計者の意図により決定できるが，C群での最低仕 様工事費との差は，本プロジェクトで平均 $9 \%$ \%方る。

3)以上の結果に基づき，目標工事費に合理的に収束できるコスト調 整方法の提案を行った。

今後の課題は，以下のとおりである。

(1)他プロジェクトへの適用可能性の検討。

(2)基本計画，基本設計段階において，C A D から得られるテフォル 卜值を含む設計情報に基づき，躯体数量を自動計算するッールの 開発。

(3)ここで提案したテフォルト值の使用を基本とするコスト調整方法 と既に提案されている概算モテルとの融合。

本研究の全般にわたって（株)ゆう建筑設計事弱所の郝藤照夫氏と井田史 子氏から多大なこ教示とご協力を頂いた。ここに記して謝意を表したい。

「注」

注 1)「建筑士法 25 集」において，コスト関連業務として，工事費予算を確定 するため必要とする類似事例の調㚗，計画実現のための工事費の検討，工 事费概算要の作成という業弱が規定され，各設計段階におけるコストプラ ンニングを設計者に対して要求している。

注2）例元は，「建筑の生産設計に関する基碳的研究」(木本健二，ほか 4 名 第8回建筑生産之管理技術シンポジウム，pp.101～108，1992.7)によれば， 工事期間中における設計変更の大きな理由の一つとして予算の配分の不遒 切さをあげている。

注 3) 例えば，「日経ARCHITECTURE」(1993 年10月11日号，pp.108 123' のアンケート調査によれば，発注者は設計者のコスト意識が低いことに特 に不渵を持ち、設計発注を行う際により重視するポイントとして建築コス トの呯価能力をあげている。

注4) 㹟義の目標工事費 $78 ， 000$ 千円の算出は，設計事務所における類似 実綪の比㪟を基に，建築費棈成比を参考にして求めた。

「参考文献」

1) 古阪秀三，捠口進治 : 集合住宅の概算法に関する研究, 日本建築学会咶画 系諭文報告集，第 363 号，pp.71 81，1986.5

2) 福詯孝之，中沜康夫，西田一彦：躯体数量の摡算に関する一手法の研究， 日本貄筑学会大会学術講演梗概集，pp.2485 2486，1983.9

3) 谷口汎邦，宮本文人，原坦，石井英楜：公立小中学校 RC 造校舎におけ る躯体数㝵の概算について, 日本建築学会計画系諭文報告集，第435号， pp.41 50, 1992.5

4) 西沢 博. 目黑昭彦: 電話局のコスト計画における概算方法の陚み（その 1 4), 日本建篡会諭文報告集，第 180 号、第 182 号、第 208 号、第 219 号, $1971.2,1971.4,1973.6,1974.5$

（1996年 5 月 10 日原稿受理，1996年 8 月 23 日採用決定） 